\title{
“O, DIE DONKIE IS 'N WONDERLIKE DING!" DIE VOORSTELLING EN UITBEELDING VAN DIE DONKIE IN ENKELE KLASSIEKE, BYBELSE EN PATRISTIESE TEKSTE
}

\author{
J P K Kritzinger (Universiteit van Pretoria)
}

\section{Inleiding}

In Upington, voor die Kalahari-Oranjemuseum, is daar ' $\mathrm{n}$ lewensgrootte brons standbeeld opgerig vir die donkie om die bydrae, wat hy gelewer het in die ontwikkeling van die Laer Oranjerivier-vallei, te gedenk. In 1986 is daar in die destydse Pietersburg voor die burgersentrum ook ' $n$ standbeeld vir die donkie opgerig om "dié miskende dier op " $n$ tasbare wyse te vereer vir sy rol in die mynwese in die streek". ${ }^{1}$ In Melbourne, Australië, is daar ook ' $\mathrm{n}$ brons standbeeld, dié keer van 'n soldaat en sy donkie, wat ' $\mathrm{n}$ medesoldaat saam met hom op sy donkie vervoer. Dit is opgerig ter ere van ene John Simpson Kirkpatrick wat tydens die Slag van Gallipoli ' $n$ hele klomp gewonde makkers se lewens gered het, deur hulle op sy donkie na veiligheid te bring. In sy Vita Divi Augusti vertel Suetonius dat Augustus ook ' $n$ brons standbeeld opgerig het vir " $n$ donkie en sy ruiter. ${ }^{2}$ In dié geval omdat die naam van die donkie, Nicon, en dié van sy ruiter, Eutychus, sy oorwinning in die Slag van Actium voorspel het. Indien ons na hierdie vier gevalle kyk, wat sommer heel lukraak gekies is, is ons lus om saam met Chris Blignaut te sing "O, die donkie is " $\mathrm{n}$ wonderlike ding".

Onlangs stap ek ' $n$ kunsgalery binne en ontdek toe daar ook 'n pragtige brons beeldjie van 'n donkie - 'n skepping van Vader Claerhout. In dieselfde galery was daar ook 'n hele aantal skilderye waarin donkies voorkom en ek het besef dat die donkie eintlik ' $n$ baie gewilde motief is vir kunstenaars. In die meeste gevalle dra die uitbeelding van die donkie by tot die skep van ' $n$ rustige landelike atmosfeer, terwyl daar dikwels ook die gevoel van eenvoud en selfs armoede daarmee geassosieer kan word.

In die afgelope paar maande is daar ook in die Afrikaanse koerante ' $n$ paar keer melding gemaak van die waarde van donkies. Met opskrifte soos "Donkie steeds 'n wonderlike ding", "Arm man se beste vriend dra swaar", "Die koning onderneem sy eretog in donkiekar", "O, die donkiekar is " $\mathrm{n}$ wettige ding in Limpopo" en "Busdiens met donkiekrag"7 is daar telkens hulde gebring aan die donkie as goedkoop en nederige vervoermiddel. Dit is verder ook opvallend dat daar by ' $\mathrm{n}$ hele aantal van bogenoemde berigte ook foto's van donkiekarre geplaas is. Dit wil dus voorkom of die donkie ook " $n$ "fotogeniese ding" is.

In hierdie artikel word daar eers ' $n$ kort oorsig gegee oor die eienskappe van die donkie en daar word ter illustrasie na enkele gedeeltes uit die Klassieke, Bybelse en Patristiese literatuur

1. Beeld Mynbou, 28/02/2003. Op die gedenkplaat aan die beeld se voetstuk staan daar die volgende geskryf: "Vanaf 1871 tot 1892 het die donkie ons eerste industrie goud Pietersburg ingedra en ingetrek."

2. Suet. Aug. 96.

3. Beeld Polokwane, 31/01/2003, p.6.

4. Beeld Johannesburg finaal, 22/06/2002, p.6.

5. Beeld, 18/08/2003, p.4.

6. Beeld, 21/08/2003, p. 11 .

7. Burger, 05/09/2003, p.4. 
verwys. ${ }^{8}$ Daar word veral gekyk na die eienskappe wat beklemtoon word wanneer mense met donkies vergelyk word. Daar word uitvoeriger na Apuleius se Metamorfoses / Die Goue Donkie gekyk, waar ' $n$ donkie die hoofkarakter is. Daarna val die fokus op 'n gedeelte uit Hieronymus se Vita Hilarionis, waarin die woestynaskeet, Hilarion, homself aanspreek as aselle, (donkietjie of eseltjie) en dié gedeelte word dan in die lig van die voorafgaande van naderby bekyk.

\section{Die verwysing na die donkie by enkele Klassieke outeurs}

Die donkie is vanaf die vroegste tye veral bekend as lasdier of pakesel, trekdier en as basiese vervoermiddel. As werkesel is die donkie ook ingespan om die ploeg te trek en om die meul te draai. Die donkie het inderdaad " $n$ baie belangrike rol vervul in die antieke wêreld. Hy was dan ook ' $n$ simbool van harde werk. Daar is " $n$ Franse spreekwoord wat sê dat as 'n mens kon ryk word deur harde werk, sou die donkie 'n paksaal vol goud gehad het. Hierdie spreekwoord lê enersyds klem op die feit dat die donkie hard werk, maar aan die ander kant word daar gesinspeel op die feit dat die donkie nie die regmatige erkenning vir sy harde werk ontvang nie. ${ }^{9}$

Maar, ten spyte van al die positiewe aspekte wat so pas genoem is, is daar ook ' $\mathrm{n}$ negatiewe sy en die volgende negatiewe eienskappe is aan die donkie toegeskryf: domheid, steeksheid, traagheid, lompheid, luiheid, ydelheid ${ }^{10}$ en vraatsigheid. 'n Ander eienskap, wat met sy vraatsigheid saamhang en wat ook vir hierdie aanbieding belangrik is, is die sterk seksuele drif van die donkie en dit hou verband met die assosiasie van die donkie met Bacchus, Silenus ${ }^{11}$ en ook Priapus.

Afgesien van die ooreenkoms in anatomie tussen Priapus en die donkie, ${ }^{12}$ is die donkie ook aan Priapus geoffer en in die $\mathrm{Fasti}^{13}$ verskaf Ovidius die volgende verklaring hiervoor: Tydens 'n partytjie van die gode het Priapus probeer om vir Vesta, wat gelê en slaap het, te verkrag. Sy is egter wakker gemaak deur die gebalk van Silenus se donkie, voordat Priapus haar kon oorval en so is sy toe deur die donkie gered. As straf vir die donkie wat sy kanse so bederf het, het Priapus toe besluit dat die donkie geoffer moet word. Aan die ander kant het die donkie Vesta se bekermling geword. Lactantius ${ }^{14}$ beskryf die offer van 'n donkie vir Priapus in Lampsacus en sê dan in dieselfde asem dat die Romeine die donkie tydens die

8. In die Reallexikon für Antike und Christentum gee Ilona Opelt ' $n$ baie volledige uiteensetting van die rol en plek van die donkie in die Ou Nabye Oosterse, Ou Testamentiese en die Grieks-Romeinse kontekste.

9. Vergelyk die opmerking van Plinius, die Ouere: "Quidquid per asellum fieri potest, vilissime constat." ("Wat ookal deur 'n donkie gedoen word, werk die goedkoopste uit") H.N. 18.44.10.

10. Vergelyk Opelt (1966:575): "Eitelkeit und falsche Selbsteinschätzung sind andere, in der spezifischen Fabelsituation auftretende und manchmal bestrafte Wesenzüge des Esels. ... Hierher gehört der leierspielende Esel. Er merkt nicht, wie amusisch er ist." ("Ydelheid en "n valse selfbeeld is ander wesenskenmerke, wat in die fabels na vore kom en dikwels bestraf word. .. . Die donkie wat die lier bespeel val ook in hierdie kategorie. Hy besef nie hoe onmusikaal hy is nie.")

11. Vergelyk Lewis \& Short (1980:1699): "Silenus: the tutor and constant attendant of Bacchus; represented as baldheaded, with short horns and a flat nose, as drunken, lascivious and mounted on an ass."

12. Vergelyk Rose, HJ OCD, (1979:876): "His symbol was the phallus and indeed he himself may almost be said to have been a phallus provided with a grotesque body" and "He was adopted as a god of gardens, where his statue (a misshapen little man with enormous genitals) was a sort of combined scarecrow and guardian deity."

13. Ovidius, Fast. 6.

14. Div. Inst. 1,21,25. 
Vestalia (fees ter ere van Vesta) vereer het, vir sy beskerming van haar kuisheid. Dit is interessant om daarop te let dat die donkie aan die een kant met Bacchus, Silenus en Priapus en daardeur met seksuele losbandigheid geassosieer word en aan die ander kant met Vesta en kuisheid.

Vervolgens word daar ' $\mathrm{n}$ paar aanhalings uit die werke van enkele Romeinse outeurs voorgehou, waarin die donkie vermeld word:

In Plautus se Aulularia sê Euclio dat hy as 'n brandarm man, hom nie kan assosieer met Megadorus, sy ryk buurman nie. Om sy dogter met Megadorus te laat trou, is net so goed as om ' $n$ donkie saam met ' $n$ os in te span. Hy vergelyk homself dus met 'n donkie en sê verder dat die ander donkies hom sal uitlag ${ }^{15}$ as hy nie kan byhou by die os nie en dat die donkies en die beeste hom selfs sal aanval.

Asini me mordicibus scindant, boves incursent cornibus.

Hoc magnum est periclum, ab asinis ad boves transcendere. ${ }^{16}$ (Aulul. 234)

Die donkies sal my verskeur met hulle tande; die beeste sal my met hulle horings aanval. Dit is baie gevaarlik om van donkies op beeste oor te klim.

Cicero noem vir Calpurnius Piso 'n donkie en sinspeel op sy dwaasheid ${ }^{17}$ wanneer hy sê dat hy (Piso) nie met woorde nie, maar met vuiste hanteer moet word:

Quid nunc te asine litteras doceam? Non opus est verbis, sed fustibus. (Pis. 73.8)

Donkie, waarom moet ek jou letters leer? Jy het nie woorde nodig nie, maar vuiste.

Elders verwys Cicero egter ook na die nuttige gebruike van muile en donkies:

Longum est mulorum persequi utilitates et asinorum, quae certe ad hominum usum paratae sunt. (Nat. D., 2.24)

Dit vat lank om die verskillende aanwendings van muile en donkies, wat inderdaad vir die gebruik van mense gereed is, na te gaan.

Vergilius verwys na die traagheid van die donkie en na sy funksie as lasdier:

saepe oleo tardi costas agitator aselli /

vilibus aut onerat pomis, lapidemque revertens /

incusum aut atrae massam picis urbe reportat.

(G.1,273)

Dikwels laai die donkiedrywer olie of goedkoop vrugte op die ribbes van die trae donkie en met die terugkomslag, dra hy ' $n$ bewerkte klip of 'n massa swart pik uit die stad uit terug.

Horatius verwys na die steeksheid en swaar las van die donkie:

demitto auriculas, ut iniquae mentis asellus, /

cum gravius dorso subiit onus.

(Sat.1, 9, 20-21)

Ek laat sak my ore, soos 'n steeks donkie, wanneer hy ' $\mathrm{n}$ vrag wat te swaar is, op sy rug dra.

Propertius verwys na die storie van Ocnos wat 'n tou vleg, ${ }^{18}$ maar soos wat hy dit vleg, is daar " $n$ hongerige donkie wat die tou staan en opvreet.

15. Die donkie is dikwels die voorwerp van bespotting. Sien ook hieronder, p. 78-79.

16. Die uitdrukking “ab asinis ad boves transcendere" cf. Otto (1962:40-43).

17. Vergelyk Opelt (1966:577): “"Esel' war in der klassischen Antike ein Schimpfwort, welches die besondere Dummheit des Beschimpften kennzeichnete." ("Die woord 'esel' was in die klassieke oudheid 'n skelwoord wat die erge domheid van die een wat uitgeskel word, aangedui het.")

18. Vergelyk Von Geisau 1979, Der Kleine Pauly s.v. Oknos, p. 271. 
dignior obliquo funem qui torqueat Ocno, /

aeternusque tuam pascat, aselle, famem! / (Prop. 4,3,18-19)

hy verdien dit eerder as die skeel Ocnos om ' $n$ tou te vleg

en vir altyd jou honger te voed, eseltjie.

Ouidius verwys na die groot ore van die donkie, sy traagheid en die feit dat hy dikwels geslaan is. Verder blyk sy simpatie met die donkie uit die verwysing na sy bejammerenswaardige lot:

Adspice, ut auritus miserandae sortis asellus /

Adsiduo domitus verbere lentus eat. / (Am. 2, 7, 11-12)

Kyk hoe die donkie met sy groot ore en bejammerenswaardige lot traag voortgaan, ingebreek deur die aanhoudende slae.

In die Appendix Uergiliana word daar na 'n uitgeputte donkie verwys en daar word vir hom ingetree omdat hy Vesta se lieflingsdier is.

lassus iam sudat asellus, /

parce illi: Vestae delicium est asinus. / $\quad$ (App. Verg. 25)

Nou sweet die uitgeputte donkietjie, spaar hom: die donkie is Vesta se lieflingsdier.

Seneca praat met Bacchus en verwys na Silenus op die donkie; hulle word altwee geassosieer met losbandigheid.

Te senior turpi sequitur Silenus asello, /

turgida pampineis redimitus tempora sertis; /

condita lascivi deducunt orgia mystae. / (Oed. 429)

Die ouer Silenus volg jou op 'n lelike donkie,

wie se geswolle slape omkrans is met kranse van wingerdrank;

die losbandige priesters lei die geheime orgies.

Martialis verwys na ' $n$ kind wie se kop en ore lyk soos die gespitste kop en lang ore van ' $n$ donkie.

hunc vero acuto capite et auribus longis, /

quae sic moventur ut solent asellorum, /

quis morionis filium negat Cyrtae? / (Mart. 6, 39, 15-17)

Maar wie ontken dat hierdie een met sy gespitste kop en lange ore, wat op dieselfde manier as donkies s'n beweeg word, die seun van die afskuwelike Cyrta is?

Juvenalis praat in Satire 9 van 'n onnosel mens as "n tweevoetige donkie:

negligit atque alium bipedem sibi quaerit asellum. (Juv. 9. 91)

Hy verontagsaam dit en soek vir homself ' $n$ ander tweevoetige donkie. ${ }^{19}$

19. Hieronymus (Ep. 27.3) verwys ook na die tweevoetige donkies: “. . revertimur ad nostros bipedes asellos et in eorum aurem bucina magis quam cithara concrepamus." ("Ons keer terug na ons tweevoetige donkies en laat klink die trompet in hulle oor, eerder as die lier.") 


\section{Enkele verwysings na die donkie in die Bybel}

Wat die Bybelse verwysings na die donkie betref, word daar vervolgens net enkele opmerkings gemaak. Daar word meer as 130 keer van donkies melding gemaak in die Bybel. Die donkie is in die Ou Testament as onrein dier beskou en sy vleis mog nie geëet word nie. Hy was ook nie as offerdier aanvaarbaar nie. ${ }^{20}$ Verder was sy dwaasheid spreekwoordelik. Nogtans is daar ook ' $\mathrm{n}$ positiewe beeld van die donkie, uit die Bybel self, maar ook uit die kerkvaders se uitleg van die betrokke gedeeltes waar daar na donkies verwys word. Die aantal donkies wat Abraham besit het, word as aanduiding van sy rykdom genoem. ${ }^{21}$ In die verhaal van Bileam waar die donkie met hom gepraat het, ${ }^{22}$ is die ironie dat die dwase dier die een is wat vir Bileam moet teregwys en hom tot insig moet bring. Die donkie sien die engel raak wat Bileam nie sien nie en die stomme dier kry ook die vermoë om te praat. Dit alles beklemtoon natuurlik die absolute dwaasheid en ongehoorsaamheid van Bileam. Wat die gedeelte oor Josef en Maria se vlug na Egipte ${ }^{23}$ betref, word daar nie in die Bybel genoem dat hulle met ' $n$ donkie gevlug het nie, maar dit blyk dat daar van vroegs af so tradisie was. Opelt $^{24}$ wys daarop dat daar gedurende die Middeleeue, in veral Frankryk, ' $n$ donkiefees (festum asinarium) gevier is om die vlug na Egipte te herdenk en dat dit later in 'n narrefees ontwikkel het.

In die uitleg van die gedeelte oor Jesus se intog in Jerusalem, ${ }^{25}$ is daar groot waarde geheg aan die feit dat Jesus op ' $n$ donkie, die vul van ' $n$ eselin, gery het. Hierdeur is ' $n$ Messiaanse profesie van Sagaria 9.9 vervul: “Jubel, Sion! Juig, Jerusalem! Jou koning sal na jou toe kom. Hy is regverdig en hy is ' $n$ oorwinnaar, hy is nederig en hy ry op ' $n$ donkie, op die hingsvul van ' $n$ donkie." ${ }^{26}$ Die donkie word as simbool van vrede (hy dra immers die Vredevors) voorgehou, maar ook as simbool van nederigheid. Weer eens word die donkie hier terselfdertyd met twee feitlik teenoorstaande begrippe vereenselwig: aan die een kant die koninklike en verhewe en aan die ander kant die nederige. ${ }^{27}$

In die allegoriese uitleg van die kerkvaders word daar veel gemaak van die twee donkies, die eselin en haar vul, wat die dissipels vir Jesus moes gaan haal. Die eselin stel die volk van Israel voor, terwyl die vul na die heidense nasies verwys. ${ }^{28}$ Hieronymus se verduideliking

20. Vergelyk Ex. 13.13, Deut. 22.10.

21. Vergelyk Gen. 12,16;32,5.16.

22. Vergelyk Num. 22, 22-33.

23. Mt. $2.13-14$.

24. Op.cit. (1966:588).

25. Mt. 21.1-11; Mk. 11:1-11; Jh. 12.12-19. (Slegs in die weergawe van Matteus word van twee donkies melding gemaak: die donkie en haar vul.)

26. Die Bybel. Nuwe vertaling. 1983. Goodwood: Nasionale Boekdrukkery.

27. In Beeld (18/08/2003:4) word berig dat koning Lerou Tshekedi Molotlegi, die 36ste monarg van die Bafokeng-stam met sy inhuldiging ook gekies het om op 'n donkiekar te ry en sy rede vir dié besluit word soos volg beskryf: "As ervare vlieënier van ligte vliegtuie en helikopters het die koning ook op dié tradisionele vervoermiddel besluit omdat hy wou wys dat elkeen ' $n$ vername rol in die monargie het - ook dié wat nie spoggerige motors besit nie. Hy het ook sy eretog na die kroning in die rytuig onderneem om sy samehorigheid met die armes te wys en te benadruk dat 'n donkiekar steeds " $n$ algemene vervoermiddel onder sy mense is."

28. Augustinus (Enarrationes in Psalmos, 33.2.5) sê dat die Joodse volk dalk nie so ingenome daarmee was om met 'n donkie vergelyk te word nie: "irascitur forte populus, quia comparatur asello in quo sedit dominus; et dicent mihi aliqui superbi et elati: ecce asinos nos fecit." ("Miskien is die volk kwaad, omdat hulle met 'n donkie vergelyk word, waarop die Here gesit het. Sommige trotse en verhewe mense sal vir my sê: 'Kyk, Hy het ons donkies gemaak."” 
hiervoor is dat die eselin swaar dra aan die las van die Wet, terwyl die jong vul nog nie daardie las gevoel het nie: ${ }^{29}$

Et sedit, inquit, in asina subiugali, quae collum et cervices lege habebat tritas. (Tract. In Marci euangelium, 7.65)

En Hy het gesit, sê hy, op 'n eselin wat gewoond was aan die juk, wie se nek en skof glad geskaaf was deur die las van die wet.

Verder was beide groepe verlore voor Jesus se koms. In sy Markuskommentaar verduidelik hy dit soos volg:

Sedit pullo asinae indomabili, qui frenos accipere non poterat, cui numquam aliquis sederat, in populo gentium: sedit in asina, in his qui credebant de synagoga. (Tract. In Marci euangelium, 7.62)

Hy het gesit op die ongetemde vul van ' $\mathrm{n}$ eselin, wat nie die teuels kon aanvaar nie, op wie niemand nog ooit gesit het nie, op die volk van die heidene: Hy het gesit op die eselin, op diegene uit die sinagoge wat geglo het.

Hieronymus verbind ook in sy Jesajakommentaar die onreinheid van die donkie met die feit dat die heidene vroeër afgode aanbid het ${ }^{30}$. Verder vergelyk hy in sy kommentaar op Amos 5.23 die gebede van die Jode met die gesnork van varke en die gebalk van donkies ${ }^{31}$. In Esegiël 23:20 word daar melding gemaak van wellustige Egiptenare en hulle liggame word met dié van donkies vergelyk." ${ }^{32}$

\section{Die donkie in Apuleius se Metamorfoses}

Wat die fisiese voorkoms van die donkie betref, maak ek verder graag gebruik van Apuleius se beskrywing in die Metamorphoses. ${ }^{33}$ Apuleius vertel die storie van Lucius, 'n baie nuuskierige kerel, wat o.a. ook baie in die toorkuns belangstel en wat in ' $\mathrm{n}$ uil wil verander. As dinge egter skeefloop en die diensmeisie, Photis, op wie hy verlief is, vir hom die

29. Comm. in prophetas minores, In Zach. 2.9: "et ascendens super asinam subiugalem, siue super pullum nouum, utrumque uidelicet populum, circumcisionis et praeputii, quorum prior grauissimum legis portauerat iugum; sicut in actis apostolorum scriptum est: nec nos, nec patres nostri potuerunt portare graue legis iugum" ("En Hy klim op "n eselin wat gewoond is aan die juk, of op "n jong vul, beide natuurlik " $n$ volk; van die besnydenis en van die voorhuid, waarvan eersgenoemde die baie swaar juk van die wet gedra het, soos in die Handelinge van die Apostels geskryf is: 'Nog ons, nog ons vaders kon die swaar juk van die wet dra"'.) Elders (Comm. in Isaiam 1.3) sê Hieronymus egter dat die donkie ook na die heidense volk kan verwys: "asinus peccatorum onere praegravatus, gentium populus accipitur, cui dominus loquebatur: 'venite ad me omnes qui laboratis et onerati estis; et ego reficiam vos"” ("Die donkie, swaar belaai met die las van sondes, word as die heidense volk opgeneem; hulle vir wie die Here gesê het: 'kom na My toe, almal wat vermoeid en belas is en Ek sal julle rus gee"'.)

30. Comm. in Isaiam, 10.32: “. . ., asinus immundus, propter idololatriam quondam gentilium, ...” (“. . . die donkie, onrein weens die vroeëre afgodery van die heidense nasies ...")

31. Comm. in prophetas minores, In Amos, 2.5: "Iudaeorum quoque oratio et psalmi, quos in synagogis canunt, et haereticorum composita laudatio tumultus est domino, et ut ita dicam, grunnitus suis et clamor asinorum, ..." ("Ook die gebed en psalms van die Jode, wat hulle in die sinagoges sing, en die ketters se saamgestelde lofprysing is vir die Here ' $n$ rumoer en, om dit so te stel, die gesnork van ' $n$ vark en die gebalk van donkies, ....")

32. "Et insaniavit libidine super concubitum eorum, quorum carnes sunt ut carnes asinorum: et sicut fluxus equorum fluxus eorum." ("En sy het waansinnig geword in haar begeerte na omgang met hulle; hulle wie se vlees (drange / geslagsdele ?) soos dié van donkies is ...”)

33. Die teks van Helm, R 1955 is gebruik. 
verkeerde salf gee, verander Lucius in ' $\mathrm{n}$ donkie. Hy maak allerhande nare ondervindinge deur, totdat hy uiteindelik hom bekeer tot die Isis-kultus en sy menslike gedaante herwin nadat hy rose geëet het. Die transformasie word soos volg in boek 3:24 beskryf:

... et haurito plusculo uncto corporis mei membra perfricui. iamque alternis conatibus libratis brachiis in auem similem gestiebam: nec ullae plumulae nec usquam pinnulae, sed plane pili mei crassantur in setas et cutis tenella duratur in corium et in extimis palmulis perdito numero toti digiti coguntur in singulas ungulas et de spinae meae termino grandis cauda procedit. iam facies enormis et os prolixum et nares hiantes et labiae pendulae; sic et aures inmodicis horripilant auctibus. nec ullum miserae reformationis uideo solacium, nisi quod mihi iam nequeunti tenere Fotidem natura crescebat.

Ek het 'n goeie hoeveelheid van die salf uitgeskep en my lyf ingesmeer. Ek het toe my arms op en af geswaai om die bewegings van ' $n$ voël na te boots. Maar geen donse en geen teken van vere het verskyn nie. Inteendeel, die hare op my lyf het dik stekelrige hare geword en my sagte vel het in ' $n$ dik dierehuid verander. Daar was nie meer vyf vingers aan my hande nie, want dit is in een hoef saamgepers. Van die onderkant van my ruggraat het 'n groot stert uitgesteek. Nou het my gesig enorm groot geword, my mond het wyd geword; my neusgate het oopgerek; my lippe het gehang. My ore het yslik groot en vol hare geword. Die enigste troos wat ek in hierdie ellendige gedaanteverwisseling kon sien, was my penis wat groter geword het - al kon ek nou nie meer vir Photis omhels nie.

Nadat hy die gedaanteverwisseling ondergaan het, kom hy tot die besef dat hy nie " $\mathrm{n}$ uil is nie en probeer hy om sy lot by Photis te bekla, maar dan besef hy dat hy nie meer kan praat of beduie nie. Hy laat sak sy onderlip en gee haar met trane in sy oë ' $n$ skewe kyk. In Apuleius se werk het ons dus te doen met ' $n$ mens in ' $n$ donkie: alhoewel hy die gedaante van ' $n$ donkie aangeneem het, het hy nogtans sy menslike bewussyn behou, maar hy het natuurlik sy vermoë om te praat verloor.

Op ' $n$ stadium het Lucius ' $n$ meisie gehelp om te ontsnap van die rowers wat hulle gevange gehou het en sy belowe om haar dankbaarheid aan hom, as die beskermer van haar vryheid en veiligheid, te bewys en hom met eerbewyse en kos te oorlaai. Verder sou sy hom goed versorg: eerstens sy maanhare kam en versier; die hare op sy voorkop krul en mooimaak; die onversorgde hare van sy stert wat gekoek en vuil was, mooi skoonmaak en hom optooi met goue behangsels soos vir ' $\mathrm{n}$ triomftog. Sy belowe aan hom roem, eerbetoon, fynproewerskos, heerlike rus en lewensgeluk. Hier sien ons eintlik ' $n$ droom van die donkie; al die dinge wat hy normaalweg ontbeer, word hier aan hom belowe en om dit te kroon sê sy dat sy die gebeure sal gedenk deur 'n skildery daarvan te maak en 'n ereplek daaraan te gee in die atrium van haar huis. Die verhaal van 'n meisie van koninklike afkoms wat op die rug van 'n donkie uit gevangeneskap ontsnap, sal deur die penne van geleerdes verewig word, ens. ${ }^{34}$ Ongelukkig, word hulle twee nie baie lank daarna nie weer gevange geneem en die rowers dreig om hulle op die wreedste manier denkbaar te vermoor. Wanneer hulle tog deur die meisie se bruidegom bevry word, ry sy haar tuisdorp triomfantelik op die donkie binne en word iets van haar belofte waar:

... pompam cerneres omnis sexus et omnis aetatis nouumque et hercules memorandum spectamen, uirginem asino triumphantem. (7.13)

... Jy sou 'n optog sien met mense van beide geslagte en alle ouderdomme en 'n skouspel wat verdien om vermeld te word: 'n jong meisie wat triomfantelik op ' $n$ donkie ry.

34. Met. 6.28-29. 
Hulle besluit selfs om hom vrye toegang tot die weivelde en die perdemerries wat daar wei, te gee, waar hy na hartelus kon sorg vir die vinnige aanwas van ' $n$ muilkudde. Ongelukkig realiseer hierdie vooruitsig nie en word hy deur die gierige vrou van die perde-opsigter ingespan om die meul te draai. Uit Apuleius se beskrywing van die donkie kan 'n mens nie anders as om simpatie te hê met die arme donkie wat al die ontberinge en swaarkry moes deurmaak nie: wat honger ly, oorlaai word, geslaan word as hy nie vinnig genoeg loop nie, verneder word, ens. Oor die interpretasiemoontlikhede van hierdie werk van Apuleius is daar uiteenlopende opinies, maar ek meen dat mens wel kan sê dat die donkie in 'n sekere sin die dierlike in Lucius vergestalt en daarom verander hy juis in " $n$ donkie - die dier wat so bekend is vir sy honger, na kos en drank en na sinlike plesier. Eers wanneer Lucius daarin slaag om hierdie drange te onderdruk, kan hy weer sy menslike gestalte herwin. Wanneer Isis (in boek 11) aan Lucius verskyn en aan hom instruksies gee wat hy moet doen om weer in ' $n$ mens te verander, word hy aangesê om rose uit die hand van 'n priester te hap en homself te verlos van die vel van die slegste en veragtelike dier. ${ }^{35}$

Wanneer dit uiteindelik gebeur en die hemelse belofte waar word, word hy verlos van die afskuwelike dierlike gesig:

... nec me fefellit caeleste promissum: protinus mihi delabitur deformis et ferina facies. (11.13)

en die hemelse belofte het waar geword: onmiddelik het die afskuwelike dierlike gesig weggegaan.

Met sy tweede transformasie of moet ons nou eerder sê "reformasie", word beskryf hoe alles weer terug verander:

ac primo quidem squalens pilus defluit, ac dehinc cutis crassa tenuatur, uenter obesus residet, pedum plantae per ungulas in digitos exeunt, manus non iam pedes sunt, sed in erecta porriguntur officia, ceruix procera cohibetur, os et caput rutundatur, aures enormes repetunt pristinam paruitatem, dentes saxei redeunt ad humanam minutiem, et, quae me potissimum cruciabat ante, cauda nusquam! (11.13).

Eers verdwyn die harde dierehare en die dierevel word weer dun, die vet maag krimp en in die plek van die donkiepote kom daar weer voete met tone en my hande is nie meer pote nie, maar word vorentoe uitgesteek vir mensetake. My lang nek word korter en my gesig en kop word weer rond; my enorme ore keer terug na hul eertydse grootte en die tande word weer klein mensetande. En dit wat my voorheen die meeste gepla het, my stert, het verdwyn.

\section{Die donkie in Hieronymus se "Vita Hilarionis"}

Vervolgens kyk ons na ' $\mathrm{n}$ gedeelte uit die Vita Hilarionis van Hieronymus, wat teen die einde van die vierde eeu (c.390) geskryf is en wat handel oor die lewe van Hilarion, die woestynaskeet. Hy vertel hier hoe die duiwel probeer het om vir Hilarion in die versoeking te lei, maar nie daarin kon slaag nie.

Titillabat itaque sensus eius, et pubescenti corpori solita voluptatum incendia suggerebat. Cogebatur tirunculus Christi cogitare quod nesciebat, et eius rei animo pompam volvere, cuius experimenta non noverat. Iratus itaque sibi et pectus pugnis uerberans, quasi cogitationes caede manus posset excludere: "ego", inquit, "aselle, faciam ut non calcitres, nec te hordeo alam sed paleis, fame te conficiam et siti, graui onerabo pondere, per aestus indagabo et frigora, ut cibum potius quam lasciuiam cogites". Herbarum ergo succo et paucis caricis post

35. Met. 11.6: “. . . pessimae mihique detestabilis iam dudum beluae istius corio te protinus exue!” (“. . en raak onmiddelik ontslae van die vel van daardie slegste en, wat my betref, veragtelike dier!") 
triduum vel quatriduum deficientem animam sustentabat, orans frequenter et psallens, et rastro humum fodiens, ut jejuniorum laborem labor operis duplicaret. Simulque fiscellas iunco texens, aemulabatur Aegyptiorum monachorum disciplinam, et Apostoli sententiam, dicentis: Qui autem non operatur, non manducet (II Thess. 3.10): sic attenuatus, et in tantum exeso corpore, ut ossibus vix haereret. (Vita Hilarionis, 5).

Gevolglik het hy (die duiwel) Hilarion se gevoelens geprikkel en hy het die normale vuur van seksuele begeertes in sy ontluikende liggaam aangesteek. As rekruut van Christus is hy gedwing om te dink aan dit wat hy nie geken het nie en om in sy geestesoog die verloop voor te stel van gebeure waarvan hy geen ervaring gehad het nie. Hy was daarom kwaad vir homself en terwyl hy met sy vuiste op sy bors slaan, asof hy met die slag van sy hand die gedagtes kon uitdryf, het hy gesê: "Eseltjie, nou sal ek sorg dat jy nie (teë)skop nie en ek sal jou nie gars voer nie, maar kaf. Ek sal jou deur honger en dors uitmergel. Ek sal "n groot vrag op jou rug laai en ek sal jou deur hitte en koue dryf, sodat jy eerder aan kos as losbandigheid sal dink". Hy het dus sy kwynende siel met die sap van plante aan die lewe gehou en na drie of vier dae met ' $\mathrm{n}$ paar droë vye. Hy het dikwels gebid en psalms gesing en die grond met ' $n$ skoffel omgespit, sodat die inspanning van die werk die uitputting van die vas kon verdubbel. En terselfdertyd, terwyl hy biesiemandjies gevleg het, het hy die leefreël van die Egiptiese monnike nagevolg en die uitspraak van die Apostel wat sê: "Maar hy wat nie werk nie, sal nie eet nie." (2 Tess. 3:10). Hy was in so mate verswak en sy liggaam só uitgeteer dat hy net vel en been was.

Wanneer Hilarion homself hier "donkie" of "eseltjie" 36 noem, gaan dit nie oor dwaasheid nie, maar spreek hy sy liggaam met sy dierlike drifte aan. ${ }^{37}$ Indien ons hierdie gedeelte bekyk in die lig van dit wat ons so pas oor die donkie gesê het en veral in die lig van Apuleius se beskrywing van die donkie, help dit ons om die beeld wat gebruik word beter te begryp. Die uithongering van die donkie word hier gebruik as " $n$ beeld om die vas te beskryf. Hilarion weerstaan die versoeking van die duiwel deur die vas. Die vas speel ' $n$ baie belangrike rol in die lewe van die woestynaskeet en daar word in die Vita Hilarionis telkens na Hilarion se dieet verwys. In paragraaf 11 word Hilarion se dieet in detail beskryf: vir drie jaar (vandat hy twintig jaar oud was) het hy net lensies wat in koue water geweek is, geëet en vir die volgende drie jaar droë brood met sout en water. Daarna het hy vir vier jaar geleef van wilde kruie en die rou wortels van sekere plante. Van sy een-en-dertigste tot drie-en-sestigste jaar het hy geleef van garsbrood en 'n bietjie opgekoote groente. Daar word klem gelê op die feit dat hy nooit voor sonsondergang die vas verbreek het nie; nóg op feesdae, nóg wanneer hy ernstig siek was. Hy het selfs op die ouderdom van vier-en-sestig jaar, toe hy besef dat sy liggaam gedaan is en gedink het dat sy einde naby is, " $n$ strenger dieet gevolg en brood uitgesny. Hieruit kan ons sien dat hy hom behoorlik uitgehonger het en net genoeg geëet het om nie van die honger om te kom nie.

Afgesien van die vas, is die kuisheidsideaal van kardinale belang vir die woestynaskeet en Hieronymus vertel in paragraaf 7 hoe die duiwel met sy versoekings hom juis op hierdie twee aspekte toegespits het. Daar staan die volgende:

Multae sunt tentationes eius, et die noctuque variae daemonum insidiae: quas si omnes narrare velim, modum excedam voluminis. Quoties illi nudae mulieres cubanti, quoties esurienti largissimae apparuere dapes!

36. Volgens Opelt (1966:578) word die verkleinwoord "asellus" in teenstelling met die peioratiewe gebruik van "asinus", as "n troetelnaam gebruik. (Adkin verwys na twee gevalle (Vita Hil. 8.1 en Epist.108.7.3) waar Hieronymus dié verkleinwoord anders aanwend. Hy beskryf die gebruik daarvan soos volg: "the meiotic diminutive asellus" en "the depreciatory diminutive asellus".

37. Paulinus van Nola (Carm.24.617) verwys ook na sy liggaam as "esel" en lasdier: "fortis anima mortificans asinum suum / pigri iumentum corporis" ("die dappere siel wat sy esel, die lasdier van sy trae liggaam doodmaak"). 
Sy versoekings was talryk en daar was dag en nag verskeie hinderlae van demone, maar as ek dit alles sou wou verhaal, sou ek die lengte van 'n boek oorskry. Hoeveel keer het daar nie naakte vrouens aan hom verskyn as hy gelê het nie, en hoe dikwels het daar nie uitspattige feesmale aan hom verskyn, wanneer hy honger was nie!

Hieronymus gebruik die uithongering van die esel as ' $n$ beeld vir selfbeheersing. Hilarion pas die vas toe en daardeur weerhou hy hom van sy begeerte na kos en drank, maar terselfdertyd word sy sinlike begeertes ook daardeur in toom gehou. ${ }^{38}$ Met die verwysing na die tipiese werk van die esel as lasdier en na die groot vrag, word hier verwys na die harde werk waarmee die liggaam belas word, om die vas nog erger te maak. ${ }^{39}$ Die liggaam, as steekse donkie, ${ }^{40}$ word tot die uiterste beproef; eintlik gemartel om die aandag af te lei van verkeerde gedagtes. Die kuisheidsideaal is natuurlik belangriker as die vas en dit sien ons uit die doelsin: ". . . ut cibum potius quam lasciuiam cogites” (“. . . sodat hy eerder aan kos as aan losbandigheid moet dink").

Hieronymus noem ook nog drie ander dinge wat hom aan die gang gehou het: hy het naamlik gereeld gebid en psalms gesing en verder ook handearbeid verrig, deur die grond om te spit en mandjies te vleg. In paragraaf 7 word daar ook gemeld dat die duiwel hom soms lastig geval het, wanneer hy besig was om te bid of psalms te sing en in paragraaf 8 word van so ' $\mathrm{n}$ insident vertel:

Oravit semel fixo in terram capite, et ut natura fert hominum, abducta ab oratione mens, nescio quid aliud cogitabat: insiliit dorso eius agitator et latere calcibus, cervicem flagello verberans: "Eia," inquit, "cur dormitas?" cachinnansque desuper, si defecisset, an hordeum vellet accipere sciscitabatur.

Hilarion was op ' $n$ keer besig om te bid met sy hoof na onder gebuig en soos die mens se natuur nou maar is, is sy aandag afgelei en het hy aan iets anders gedink. ' $n$ Drywer het toe op sy rug gespring, hom met die hakke in die sy geskop en met 'n peits teen sy nek geslaan en vir hom geskree: "Kom nou, waarom is jy so aan die slaap?" En terwyl hy van bo af geskater het van die lag, wou die drywer weet of hy moeg is en of hy gars wil hê.

Dit lyk of hy hier weer die beeld van die donkie gebruik, al word die donkie nie spesifiek genoem nie. Dit is veral die verwysing na die gars (hordeum) wat aansluit by die gedeelte in par. 5 waar hy sê dat hy die donkie nie gars nie, maar kaf sal voer. Ook die feit dat die drywer die dier so skop en slaan, pas in by die algemene beeld van die donkie as 'n dier wat dikwels geslaan is. ${ }^{41}$ Nog ' $n$ interessante ding wat hier genoem word, is die drywer wat vir Hilarion lag. Die donkie was dikwels ' $\mathrm{n}$ voorwerp van bespotting, ${ }^{42}$ hetsy weens sy groot ore, ${ }^{43}$ hetsy

38. In Apuleius se Metamorphoses is ' $n$ noue verband tussen die begeerte na kos en drank en ander sinlike begeertes. Dit word o.a. duidelik uitgebeeld in 'n uiters suggestiewe toneel (2.7), waar Photis staan en kosmaak en Lucius haar laat weet dat hy baie uitsien na die twee geregte: dit wat op die stoof is en na haar wat voor die stoof staan.

39. Die verwysing na die hitte en koue is ook interessant: Plinius, die Ouere (H.N. 8.167) sê dat die donkie glad nie koue kan verdra nie.

40. Vergelyk Adkin: "The saint's problem is with the recalcitrance of his own sensuality. The ass was the palmary type of both stubbornness and lust."

41. Die donkie se vel is soms gebruik vir die makk van ' $n$ trom en dan is die arme donkie selfs na sy dood nog steeds geslaan! (Vergelyk Phaedr. 4.1).

42. Die tema van spot is ook belangrik in die Metamorphoses van Apuleius en dit is veral prominent in hoofstuk 3.

43. Hieronymus waarsku in Ep. 125.18 soos volg teen iemand wat, jou in jou teenwoordigheid vlei, maar agter jou rug met jou die spot dryf: "ne credas laudatoribus tuis, immo inrisoribus aurem ne libenter adcommodes, qui cum te adulationibus foverint et quodam modo inpotem mentis effecerint, si subito respexeris, aut ciconiarum deprehendas post te colla curvari aut manu auriculas agitari asini aut 
weens sy gebalk. Verder is iemand veral 'n donkie genoem wanneer hy as ' $n$ dwaas beskou is. $^{44}$

Forstner dui aan dat die beeld van die donkie ook positief gebruik word om te verwys na diegene wat hulself in nederigheid aan ' $n$ heilige dissipline onderwerp wat hulle soos ' $n$ opgelegde las dra en verwys na die voorbeeld van Fransiscus van Assissi wat sy liggaam ook as "broer esel" aangespreek het. ${ }^{45}$ Dit is myns insiens nie onmoontlik dat Hieronymus ook op "n manier hierdie positiewe aspek in gedagte het, wanneer Hilarion homself hier as "aselle" ("donkietjie") aanspreek nie. In 'n sekere sin word die woestynaskeet se lewe van ontbering beskryf as ' $n$ nederige onderwerping aan ' $n$ heilige toewyding wat soms ook as " $n$ las ervaar word.

In ' $\mathrm{n}$ artikel van Adkin $^{46}$ wat eersdaags gaan verskyn, dui hy oortuigend teenoor Weingarten ${ }^{47}$ aan dat daar nie gronde is om te bewys dat Hieronymus bekend was met die werk van Apuleius nie. Alhoewel hierdie artikel geensins ' $n$ poging is om aan te dui dat Hieronymus wel vertroud was met Apuleius se werk nie, is die skrywer nogtans van mening dat dit sinvol is om Hieronymus se aanwending van die beeld te bekyk in die lig van Apuleius se Metamorphoses, omdat die werk vir ons 'n goeie aanduiding gee van die simboliek van die donkie in die tweede eeu $\mathrm{nC}$. Verder het ons ook gesien dat daar ander aspekte is wat ter sprake gekom het in die betrokke gedeelte van die Vita Hilarionis, wat aansluit by temas wat prominent is in die werk van Apuleius, naamlik die verband tussen kos en sinlike begeerte; die tema van selfbeheersing (of gebrek daaraan), wat hiermee saamhang en die tema van bespotting, wat ook by die beeld van dwaasheid aansluit.

\section{Slot}

Ten slotte kan ons sê dat Hieronymus die beeld of metafoor van die donkie baie sinvol aanwend in hierdie deel van die Vita Hilarionis en twee uiters belangrike aspekte van die woestynaskeet se lewe, te wete die vas en die kuisheidsideaal, duidelik hierdeur belig. Verder kan paragraaf 5 ook as ' $\mathrm{n}$ uiters belangrike paragraaf van die Vita Hilarionis beskou word, omdat, afgesien van die vas en die kuisheidsideaal, die rol van gebed, die sing van psalms en die belangrikheid van werk, - uiters belangrike aspekte in die lewe van die woestynaskeet — alles hier aan die beurt kom.

aestuantem canis protendi linguam" ("Moenie hulle glo wat jou prys en moenie goedsmoeds jou ore uitleen aan spotters, wat jou met hulle gevleiery laat goed voel en op "n sekere manier sorg dat jy kop verloor nie. As jy skielik omgekyk het, sou jy sien dat agter jou rug hulle nekke soos ooievaars s'n gedraai word of dat donkie-ore met hulle hande gemaak word of dat hulle tonge uitgesteek word, soos dié van 'n hond wat baie warm kry.")

44. In Augustinus se Contra Iulianum opus imperfectum, (4.56) beskryf Julianus vir Augustinus as ' $\mathrm{n}$ aanklaer van heiliges en " $n$ beskermheer van donkies (". . accusator sanctorum et patronus asinorum"). In dieselfde gedeelte spreek Augustinus op sy beurt vir Julianus as "donkie" aan: "Cur ergo non intelligis, asine, ..." ("Waarom begryp jy dan nie, donkie, ...")

45. Op.cit. (1986:254): "So wird das Bild des Esels in verschiedener Weise auf solche angewendet, die sich in Demut einer heiligen Zucht unterwerfen. Der hl. Franz von Assissi nannte seinen Leib "Bruder Esel" und nötigte ihn, die Lasten der Buße und schweren Arbeit zu tragen."

46. Adkin, N 2003. Some alleged echoes of Apuleius in Jerome.

47. 1997:383-89. 


\section{BIBLIOGRAFIE}

Adkin, N 2003. Some alleged echoes of Apuleius in Jerome. (Voorgelê vir publikasie in Classical Philology)

Forstner, D 1986. Die Welt der christlichen Symbole. Innsbruck: Tyrolia-Verlag.

Fuhrmann, M 1983. Christen in der Wüste. Drei Hieronymus-Legenden. Zürich-Munchen: Artemis Verlag.

Helm, R (ed.)1968. Metamorphoseon Libri XI. in Bibliotheca scriptorum Graecorum et Romanorum Teubneriana. Leipzig: Teubner.

Kech, H 1977. Hagiographie als christliche Unterhaltungsliteratur. Studien zum Phänomen des Erbaulichen anhand der Mönchsviten des hl. Hieronymus. Göppingen: Verlag Alfred Kümmerle.

Opelt, I 1966. Esel. RAC 6, 564-595. Stuttgart: Anton Hiersemann.

Otto, A 1962. Die Sprichwörter und sprichwörtliche Redensarten der Römer. Hildesheim: Georg Olms Verlagsbuchhandlung.

Walsh, P G (transl.) 1994. Apuleius, The Golden Ass. Oxford: Oxford University Press.

Weingarten, S 1997. Jerome and the Golden Ass. Studia Patristica 33:383-389. 